\section{SELECTIVE DEMOLITION OF REDUNDANT AND EARTHQUAKE DAMAGED BUILDINGS IN TURKEY}

\author{
Soofia Tahira ELIAS ÖZKAN
}

Received: 01.08.2011, Final Text: 30.12 .2011

Keywords: damaged buildings; redundant buildings; disasters; demolition; deconstruction.
When a building reaches the end of its useful life or suffers severe damage during a disaster, it has to be demolished. However, not much is known about how the demolition work proceeds, or how is it regulated in Turkey; what machinery, tools and techniques are used; what material is salvaged and what dumped as waste; and how it is disposed off. Answers to these questions were sought through research conducted in İstanbul, Ankara and İmir, as well as in earthquake affected areas in Turkey. Safety was an issue that became a concern during the course of these studies.

This paper presents an overview of information on pertinent legislation and regulations; the conventional procedure for building demolition work; and case studies on selective demolition of redundant and damaged buildings. Based on the findings of the case studies certain recommendations are made to enhance safety and feasibility of building disposal projects.

\section{INTRODUCTION: BUILDING DEMOLITION IN TURKEY}

Architects design for posterity and buildings are expected to stand forever, but reality has it otherwise. Very few buildings survive for more than a century. Most buildings are demolished at the end of their useful life and have to be disposed off in one way or another; from dumping as debris in landfills to dismantling and recycling the whole structure.

When buildings are being demolished, it is possible to salvage some of the material and components for reuse elsewhere. Such material is sometimes sold directly from the demolition site but is usually transported to the contractor's yard where it is stored, displayed and sold. The salvaged building material market in Turkey is so profitable that partial deconstruction has been observed even in dangerously damaged buildings that were earmarked for demolition in the aftermath of an earthquake (Elias Özkan, 2003). 
In order to salvage reusable components from a building it has to be deconstructed; i.e. the whole construction process is reversed (Kibert et al., 2000) and the building components are dismantled one by one. However, when it is not feasible to deconstruct the whole building, partial deconstruction is carried out first and then the remaining structure is demolished. The conventional method of building disposal in Turkey is also a mix of both partial deconstruction and demolition; this procedure is commonly referred to as 'selective demolition'.

In developed countries, an increasing awareness of and concern for environmental issues is also one of the main reasons why such pains are being taken to deconstruct a building rather than disposing it off through speedy demolition. Additionally, the wish to reduce their carbon footprint has also encouraged some countries to initiate steps towards reducing the environmental impact of both construction and demolition (C\&D) waste. In Turkey, such initiatives have led to the formulation of legislation that governs the disposal of C\&D waste in general and the demolition of structures in particular. Although, these laws were passed to regulate the demolition of structures only; they are also conducive to the deconstruction of buildings.

Unfortunately, despite the pertinent legislation and regulations, deconstruction and demolition are poorly regulated activities that are still being conducted in the traditional way. Most of the demolition work is done manually; it is labour intensive and therefore requires simple tools or hand held machinery. On the other hand, developed countries are using various machines and specialised tools to deconstruct the simplest of buildings.

Very old buildings of simple construction configurations are generally easier to demolish as the variety of material is limited and they are also less of a health hazard as toxic or carcinogenic material like volatile organic compounds (VOC), asbestos and lead-based paints may not be present. Components, such as doors, windows and wrought iron grills in such buildings often have an aesthetic or antique value and are an added boost to the contractor's income. As the complexity and size of buildings increases so does the technology needed to pull them down safely.

In Turkey every large city has its share of outlets for second-hand building materials and components that were salvaged from demolished buildings. Most of these outlets are owned by the demolition contractors themselves who are, in fact, providing a very worthy service to the informal construction sector by supplying low-cost material (Elias Özkan, 2002). Since they are able to sell material which does not actually cost them anything the contractors try to recover as much material as possible by using conventional deconstruction and demolition techniques. These techniques are described in the following sections.

Despite the fact that the demolition industry is doing a great service by recycling building material, components and structures, it is a fairly unknown entity in Turkey. Published information in Turkish or English with regard to its operations, activities and impact is practically nonexistent. On the other hand, in many parts of the world extensive research is being conducted on recovery, reuse and recycling of building material as well as the demolition and deconstruction of buildings. In order to share the findings of their research and formulate solutions to related environmental problems researchers and academicians came together 
under the umbrella of the Conseil Internationale du Batiment (CIB) in 2000 and formed a Task Group (TG), designated as 'TG39 on Deconstruction'. Members of TG39 hailed from Australia, Canada, Germany, Israel, Italy, Japan, Netherlands, New Zealand, Norway, Portugal, Poland, Spain, Sweden, Turkey, USA, UK and Venezuela. Findings of research conducted in Turkey have been presented mostly at meetings of the task group and international conferences (Elias Özkan 2002, 2003, 2005).

Within the sphere of this research; demolition companies in the three largest cities of Turkey, İstanbul, Ankara and İzmir, were contacted and their yards were visited, in order to gather information on their work and wares. Further, demolition sites in Ankara and earthquake devastated areas in Kocaeli and Adana were visited and ongoing deconstruction and demolition work on a total of 21 buildings was observed and recorded. Furthermore, information on legislation, regulations and statistics was obtained from official sources. This paper presents an overview of information collected over the past 12 years on pertinent legislation and regulations; the conventional procedure for building demolition and case studies on selective demolition of redundant and damaged buildings.

\section{Legislation and Regulations}

Waste is an ever growing menace of the modern society and demolition waste, being bulky and at times hazardous in nature, is aggravating the problem of managing solid-waste disposal in cities. According to the Turkish Ministry of Environment and Forestry, C\&D waste constitutes 13 and $29 \%$ of the urban solid waste, by volume and by weight respectively. This amount is produced during construction, demolition and renovation of residential and commercial buildings, as well as roads and bridges (Öztürk, 2005). Statistics on demolition waste are not available separately; however, according to a previous study by the author the volume of demolition waste generated in only one of the eight municipalities in Ankara was estimated to be between 36 to 55 thousand cubic meters annually. This amount was calculated from 325 building permits issued during a single year for new construction within the jurisdiction of the Çankaya municipality. Such permits contain information on the volume of rubble present on site, which is an indication of previous demolition activities there. This information was recorded to calculate the amount of fee to be paid, by the owner to the municipality, for the disposal of rubble in a designated landfill (Elias Özkan, 2001).

\section{a. Demolition Waste}

A comprehensive Waste Management Action Plan for the period 2008 to 2012, was prepared by the General Directorate of Environmental Management under the aegis of the Ministry of Environment and Forestry. This 295 page document was produced in compliance with the EU Directives and it covers in detail the policies and legislation in place, the types of wastes generated, the relevant waste and environmental statistics, and the recommended waste management strategies (Ministry of Environment and Forestry, 2008). The categories of wastes accounted for in the Action Plan, as well as in the solid waste statistics (TUIK, 2008), are related to domestic, hazardous, hospital, and packaging (plastics, paper, glass and metal) wastes only.

Surprisingly, There is no mention of C\&D waste in the Action Plan nor in the waste statistics despite the enormous amounts of C\&D waste in the waste stream and also despite the fact that four years before the 
Action Plan was devised, regulations on 'Excavation, Construction and Demolition Waste Control' had already been formulated and promulgated. The main aim of this detailed legislation was to outline the technical and administrative policies as well as the rules and regulations to be followed in dealing with excavation, construction and demolition waste without harming the environment. (Ministry of Environment and Forestry, 2004) The intentions were:

- to minimize waste production at source,

- to re-use or recycle the excavated soil, and C\&D waste;

- to prevent mixing of the excavated soil and the C\&D waste;

- to separate the waste at source and promote selective demolition;

- to hold the producers responsible for the cost of their waste disposal; and

- to hold individuals, departments and organizations in charge of waste management responsible for taking the necessary precautions. In doing so it is recommended that the following steps be taken to manage $C \& D$ waste:

1. reduction at source,

2. collection, temporary accumulation and transportation for reusing or recycling, or

3. appropriate disposal.

Laws governing most aspects of the construction and demolition works exist but unfortunately they are not applied stringently enough due to a lack of checks and resources. Same is the case with recycling waste and waste disposal; the regulations are there but the awareness of these regulations is missing and the resources to implement them are limited (Elias Özkan, 2005).

\section{b. Demolition Works}

In order to regulate demolition activities in Turkey, the Ministry of Development and Housing has prepared a 'Technical Contract for Demolition and Dismantling', which covers all technical aspects of such works (Turkish Ministry of Development and Housing, 2000). This document requires that demolition contractors:

- prepare a demolition action plan in accordance with the type of structure and materials of construction;

- take stringent precautions for human safety and for reducing environmental pollution;

- use proper scaffolding, machinery and tools;

- employ trained workers;

- recover as much building material for reuse or recycling as possible; and

- store the recovered material properly until removal from site.

Although, demolition contractors may be required to follow these guidelines when they bid for public works, they do not feel obliged to abide by them in private projects nor are their private clients aware of these regulations (Elias Özkan, 2005).

\section{c. Demolition Permits}

Depending on the location and also on the size and nature of the building to be pulled down, permits may be required prior to starting the demolition work. Some countries make it mandatory while others have 
relaxed regulations. Building control authorities may or may not have structured guidelines -from a demolition action plan to a waste disposal strategy- that must be followed in order to obtain a demolition permit. The situation varies from country to country and even from urban to rural settlements.

The ten country reports on deconstruction by members of TG39 (Chini, 2005) mention the requirement, by law, of submitting a work plan for demolition projects prior to the commencement of works; this plan has to outline the disposal procedures for waste material also. Additionally, some countries impose an obligation on the demolition team to minimise the amount of waste to be disposed and maximise recycling of materials; however, the methods and techniques are not outlined therein. Apparently, recycling is encouraged by these regulations; yet the building codes and standards of some countries, including Turkey, do not encourage the use of recycled material for new constructions.

\section{d. Worker Training and Safety}

Legislature exists to ensure the health and safety of workers as well as the safety of operations to avoid accidents and environmental pollution. The Turkish Ministry of Works has devised strict measures for the training, safety, health and employment conditions of the workers, which are enforced through laws, bye-laws, rules and regulations. These measures cover the different aspects of all types of works. For instance, the 'Regulations for Health and Safety of Construction Workers' include the health and safety issues for construction as well as demolition workers. These regulations also stipulate that only trained workers should be used in dangerous jobs; however, the demolition industry generally ignores this rule (Elias-Ozkan, 2005); and both construction and demolition contractors are known to employ mostly unskilled labour to keep the costs down.

\section{Sequence of Deconstruction and Demolition Works}

Buildings are considered to have an average life span of 50 to 60 years; after that they are declared redundant and demolished, mostly to clear the site for new ones. There are many ways to demolish a building and each depends on the type and size of the building, the material and techniques employed in its construction, the machinery and tools available, the type of material to be salvaged or dumped and the skills of the crew. The following sections provide more information on these factors.

\section{a. Machinery and Tools}

Demolition contractors can choose from a variety of methods ranging from manual demolition to the use of explosives. Standard demolition machinery such as front-end loaders, backhoes, excavators, bulldozers and trucks are used extensively in conjunction with cutting, drilling, and sawing techniques. Demolition can be carried out with machines, explosives or manual tools, or a combination thereof. For example pneumatic drills and excavating machines are used to break down structural components that cannot be broken down manually with sledgehammers.

Machinery and tools used for the demolition job can be grouped according to the method employed; i.e. mechanical, chemical or manual. The mechanical method depends on impact breaking of the structure and walls. It can be done with heavy steel or cast iron ball, pneumatic or hydraulic breakers; and other specialised attachments for excavators, such as 
hydraulic shears, buckets, boom mounted hydraulic percussion breakers and pusher arms. These machines either crush and break the building components into smaller pieces; or cut and grind the structure by dividing into smaller elements. Explosives are used only in large demolition projects by specialized teams. On the other hand, manual demolition depends on muscle-power with portable tools such as power saws, crowbars, mattocks, pneumatic drills, sledge-hammers and pickaxes.

\section{b. Materials of Construction}

In Turkey buildings are constructed mostly with reinforced cement concrete (RCC) skeleton structures and masonry walls of concrete or aerated concrete blocks or extruded clay brick. Walls and ceilings are generally rendered with sand and cement or lime plaster. Utility lines for water, electricity, and telephones etc. are embedded into the walls and ceilings before rendering with cement-concrete plaster; while plumbing is embedded in the floors before pouring the levelling concrete. The floor finishing layer is mostly composed of ceramic, terrazzo or marble tiles in a bed of mortar; or wooden parquet / strip flooring fixed with glues.

In older buildings masonry walls used to be built with solid brick that were quite strong and the lime and sand mortar that was used to bond them was weaker in comparison. Hence, it was possible to prize pry them loose one by one, using a double-pronged curved wrench with a long handle for increased leverage, and thus dismantle the masonry wall with minimal damage to the bricks (Elias Özkan, 2002).

In newer buildings, the concrete mortar used for laying the brick is stronger than the extruded hollow brick itself; therefore, it is not possible to deconstruct the walls without breaking the bricks into pieces. Most demolition contractors do not consider it worth their while to salvage the brick or masonry blocks; hence, they reduce the structure into rubble as fast as possible. The resulting mound of rubble is mostly left behind on the site, to be removed later by the building contractor. Construction that is carried out with concrete as the main building material renders the complete deconstruction of a building difficult, if not impossible. Consequently, the procedure adopted in pulling down a building is a combination of both deconstruction and demolition.

\section{Materials Salvaged}

All of the demolition companies in Turkey concentrate on recovering only such material from the structure which brings in the most profit, which is easy to recover without significant damage and which can be sold within a few months. Material salvaged includes boards, rafters, battens and joists, steel reinforcement, aluminium components, corrugated roofing sheets, roofing-tiles, wrought iron grill-work, doors, fenestration, bathroom fittings and fixtures, pipes, built-in cupboards, kitchen cabinets and sinks (Elias Özkan, 2002). On the other hand, masonry units and floor or wall tiles are rarely recovered intact from the structure; they are usually dumped as rubble even though it is possible to recycle them into aggregate. Nevertheless, demolished buildings can be looked upon as 'secondary quarries' for aggregate (Blengini, 2009).

Lack of space in the yard may also be a deciding factor for dumping some demolition material that may ordinarily have a market value. Such material is usually bulky and the profit it is expected to bring in does not justify the 
Figure 1. Stained glass windows of a building on Farabi Street in Ankara, that was demolished: (a) the lower window was dismantled but the one on top was discarded for lack of appropriate rig; (b) close-up of the window from inside the stairwell.
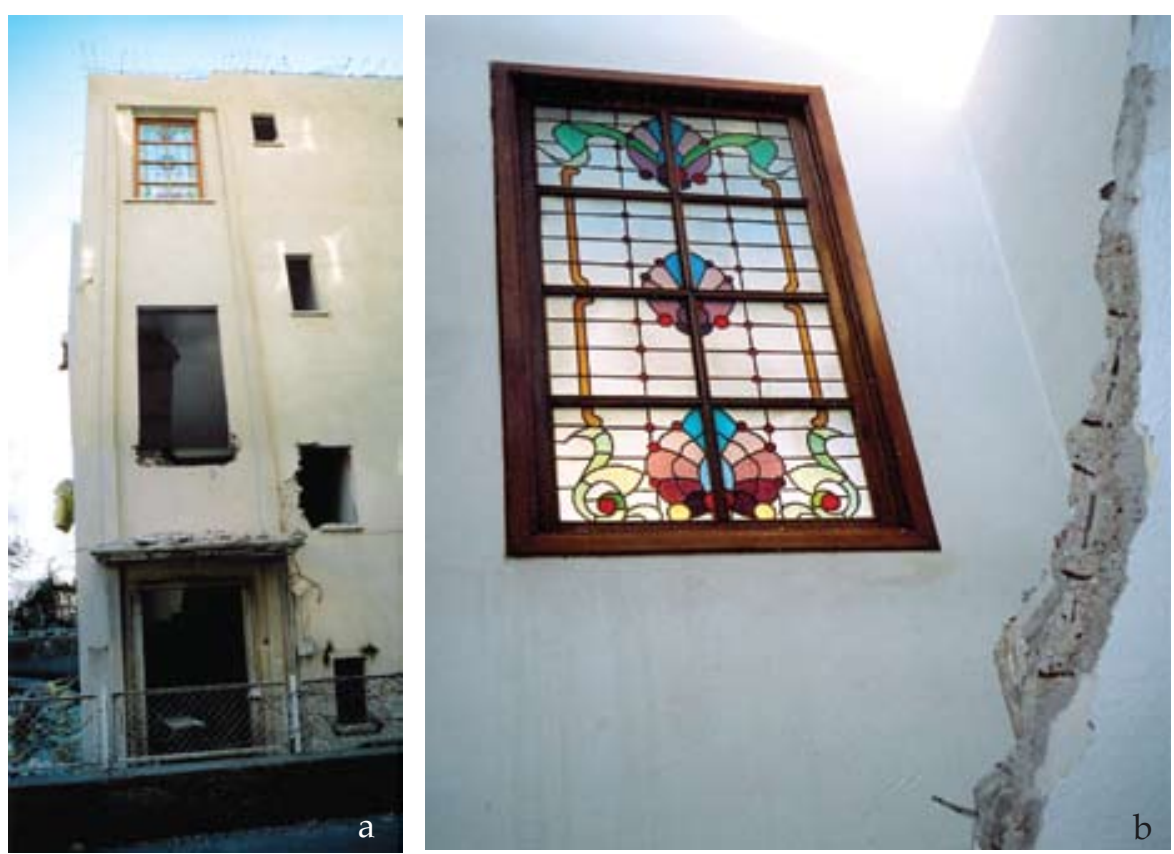

space it occupies. Hence, yard owners prefer to stock up on materials that not only bring in a quick profit, but that take up less space.

Another reason may be the lack of appropriate machinery, tools or rig needed to salvage a particular component. For example, there were two stained glass windows in the stairwell of the building shown in Figure 1 and a ready buyer was offering a reasonable price for both of them. However, the demolition contractor was able to salvage the lower one only as the one on top could not be dismantled for lack of a proper rig. Sadly, it was demolished and dumped as waste.

\section{Case Studies on Selective Demolition}

Over the past decade, deconstruction or demolition work on 21 buildings has been observed and recorded at various stages while work on 4 of these buildings was monitored from start to finish. Seven of the buildings were located in the earthquake hit areas and 14 were in the city of Ankara. Of the buildings in the earthquake area 2 were being demolished and 5 were being partially deconstructed before being pulled down. Whereas, 2 of the 14 case studies in Ankara were on demolition works and 11 on partial deconstruction. It should be noted here that buildings in Turkey are constructed in a manner that prevents their complete deconstruction; hence, selective demolition is carried out. The procedure for demolishing redundant and damaged buildings is given in the following sections.

\section{a. Selective Demolition of Redundant Buildings}

A building is not demolished as it stands; it has to be stripped of all removable components such as fittings, fixtures and finishing material before starting the demolition work. Only materials that cannot be removed easily are left adhering to the concrete structure such as plaster, terrazzo flooring, ceramic tiles, etc. This process called 'soft stripping' is done manually with portable tools in the following sequence (Elias Özkan, 2002): 
1 all sanitary ware, cupboards, kitchen and bathroom fittings, lights, fans, boilers, heaters, etc., are dismantled;

2 panelling, removable flooring, decorative mouldings, etc are stripped from the surfaces;

3 all doors and windows are taken out from the rooms;

4 internal staircases and balustrades are dismantled; and

5 roofing material is taken down.

Even in very large buildings the interior has to be stripped by hand so that when the concrete structure is demolished there is no contamination. It makes sense, therefore, that during this manual process resource recovery is maximised both in terms of quantity and quality

\section{a.1. Deconstruction Process}

Deconstruction is an expensive and time consuming process since it is done manually; hence, the demolition contractors choose to recover only those building components which have a resale potential. They use crowbars, hammers and de-nailers to dismantle fenestration, door sets, built-in cabinets and cupboards, and other fittings. Very rarely, old brick is recovered from a building where the mortar has deteriorated with time and the bricks can be loosened with crow bars (Elias Özkan, 2002).

The number of workmen employed can vary from as many as fifteen to as few as five depending upon the size of the structure to be demolished. In the case of a single family unit, which is usually a single storied building consisting of 3 to 5 rooms, the demolition contractor can recover all resaleable material within a single day. Two workers are required to take down the roofing tiles, another two are employed to remove fittings and fixtures and the fifth is a general factotum. The roof-tiles, fittings and fixtures can be salvaged during the first half of the day, while the rest of the day is spent in dismantling the timber roof structure and fenestration (Elias Özkan, 2002).

\section{a.2. Sorting, Cartage and Storage}

Once the building is soft-stripped the salvaged material is stored on site in separate groups; e.g. doors are stacked together in one place and windows in another. It is then easy to load them on the vehicle that transports them to the contractor's retail yard, where it is unloaded and sorted again according to the degree of damage, if any, and stored properly. Proper sorting and storage also helps to save the material from being contaminated, soiled or damaged; otherwise its quality or value is decreased further after being removed from the building structure.

\section{a.3. Demolition Process}

After the building has been stripped and the salvaged material removed from the site, work is started on demolishing the bare structure following a logical sequence; a bottom up approach is used to break the floor slabs and a top-down technique is adopted for the walls (Elias Özkan, 2002).

The floor slabs are demolished first with pick axes, starting from the lowest one and moving on to the one above until the last slab is reached. This is done to prevent the building from collapsing in an uncontrolled manner due to the weight of the debris collecting on the slab below. The walls are knocked down with sledgehammers; starting from the topmost floor down to the ground level. Any steel reinforcement from the RCC structure is removed for recycling as well as for reuse in informal construction (Elias 

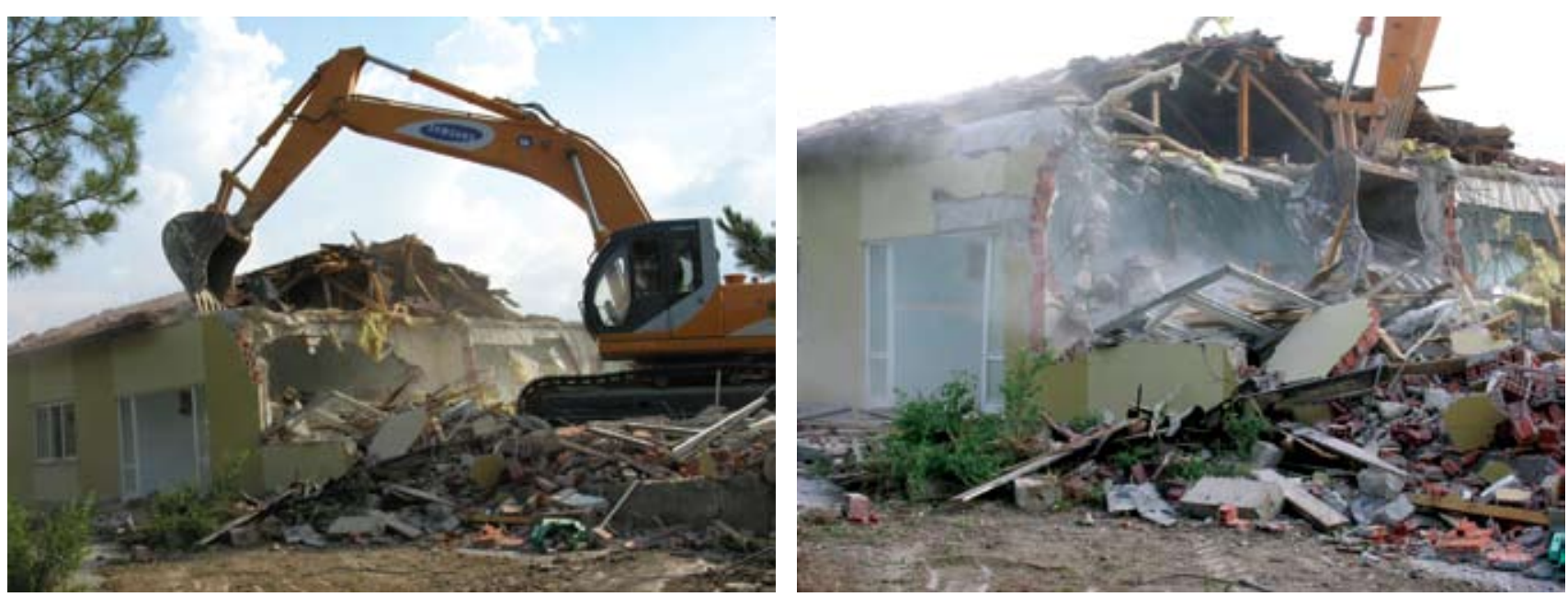

Figure 2a, 2b. Mechanized demolition of a single storey building on METU campus in Ankara.
Figure 3a, 3b. Mechanized demolition of a small building in Karlsruhe, Germany. The special excavator arm dismantled and deposited the building materials / components in sorted piles.
Özkan and Düzgüneş, 2002). Sometimes, if the building is higher than 2 floors, the top floors are demolished with all the aforementioned machinery and tools until it is reduced to a skeleton low enough to be bulldozed.

On the other hand; when speed is of the essence, the soft-stripping stage is also abandoned and excavators are used to pull down the building. This was the case of a fairly new single storey building on METU campus in Ankara, which was demolished with an excavator within a single day (Figure 2). The $300 \mathrm{~m}^{2}$ building was constructed with hollow brick walls on a concrete foundation, a clay tiled wooden roof on a concrete slab, double-glazed PVC fenestration and proper heat and water proofing. Despite the fact that it would have been fairly easy to recover the fittings, fixtures, doors, windows, and the roofing material; which were all in good condition, no attempt was made to salvage any of it. The next day, the mixed debris was loaded into trucks and transported to a landfill.

Even if excavators are employed for quick disposal it is possible to selectively demolish a building and salvage much of the material for reuse, provided that appropriate excavator arm attachments are used. For example, a small building in Karlsruhe was selectively demolished in this manner and the material salvaged was collected in separate piles using the versatile arm of the excavator (see Figure 3). Additionally, steps were taken to reduce air pollution; such as hosing down the building while it was being demolished.
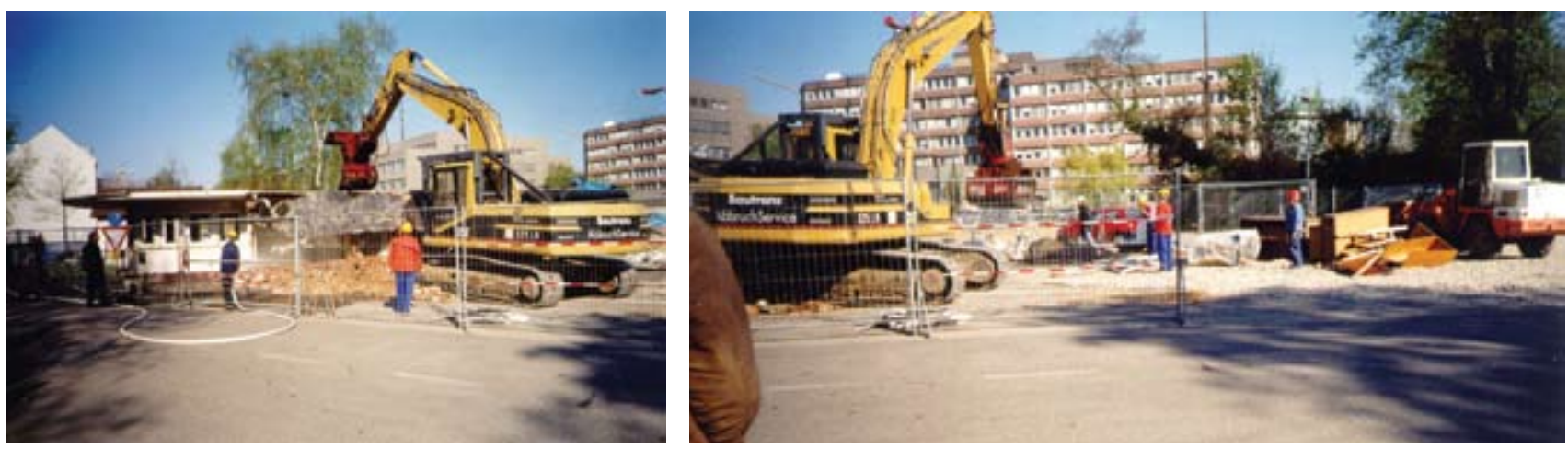

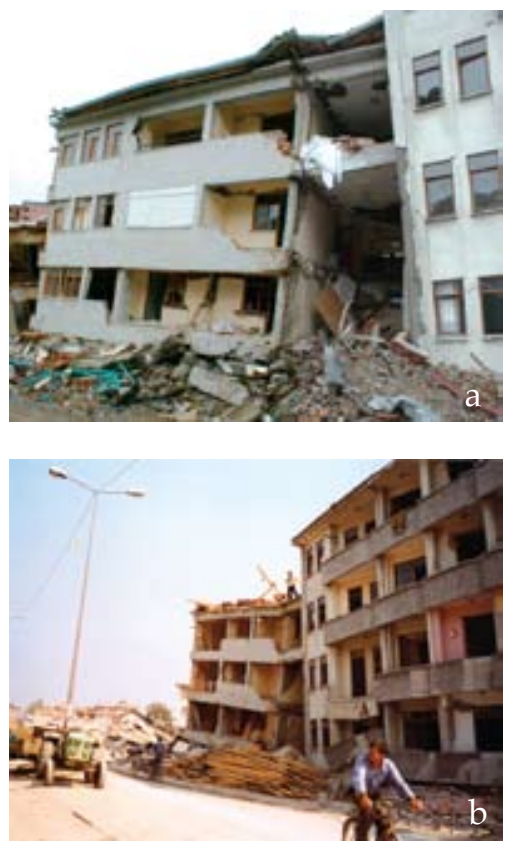

Figure 4. (a) A building damaged severely during the August 1999 earthquake in Adapazarı. (b) The building has being stripped of any reusable building material (doors, windows, tiles); and timber from the roof is being salvaged.

Figure 5. Mechanized demolition of a severely damaged building after the May 2011 earthquake in Simav. Heavy machinery was used to eat away the building from the front, leading to an uncontrolled partial collapse. Sources: CHA (b,c), DHA (a,d,e,f) (2011).

\section{Selective Demolition of Disaster Damaged Buildings}

The sequence described in the previous section for demolishing redundant buildings, cannot be followed for the demolition of buildings that have been severely damaged during a disaster such as an earthquake. In the aftermath of an earthquake such buildings have to be pulled down in a hurry so as to clean up the area before further aftershocks can cause uncontrolled collapse and lead to a further loss of life and property.

During the 1999 earthquake in Turkey thousands of buildings had suffered severe damage and demolition work was hastily conducted without any planning or technical guidance. In the resulting chaos the demolition, site clearance and salvaging activities proceeded concurrently in the disasterstricken areas (Elias Özkan, 2003). Deconstruction was carried on even in the precariously tilted buildings in order to recover as much building material as possible and demolition work was being conducted without any concern for safety (Figure 4). Recovery efforts were concentrated towards salvaging those building materials, which, as in the case of intentional-demolition projects, had a resale value in the market for secondhand building materials. Likewise, concrete that was ordinarily dumped into landfills was also discarded after the steel reinforcement had been recovered from it.

In Kocaeli, the deconstruction work was done manually but excavators, cranes, bulldozers, power shovels, pneumatic drills, and dump trucks had to be employed for building demolition and site clearance (Elias Özkan, 2003). Jaw-like attachments were used to break or cut concrete and since the arm of the excavator had limited reach the excavator was literally eating its way into the building. This approach, which was also used in Simav after the May 2011 earthquake, not only caused immense pollution but was also very dangerous. As shown in Figure 5, the debris created by such haphazard demolition made recovery of materials even more difficult. This figure shows the process of mechanized demolition of a building
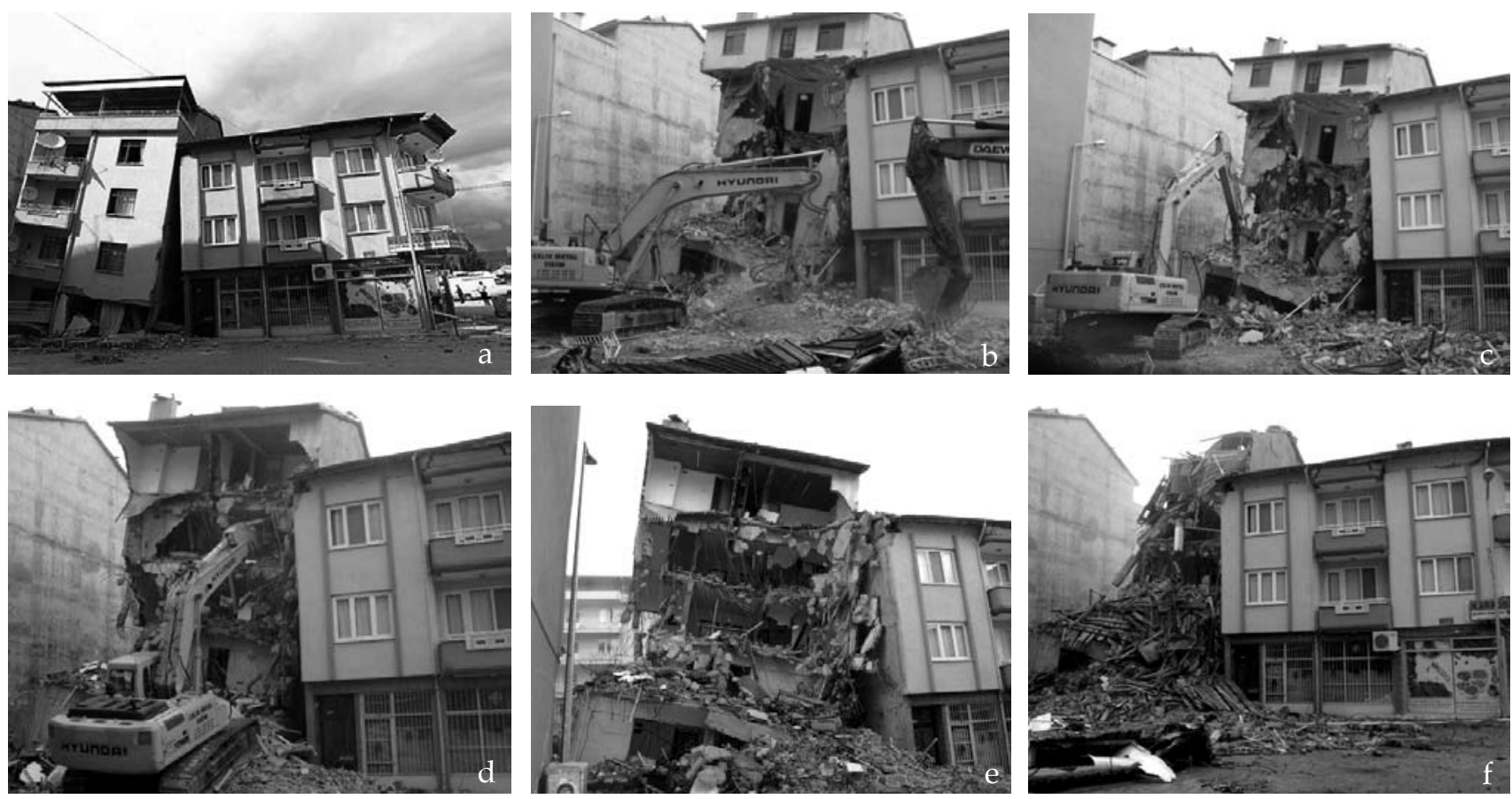
Figure 6. Lack of safety precautions are observed during demolition work. (a) A worker standing on the top of the fourth storey wall without a safety belt or helmet; and (b) another standing on the very wall he is breaking with a sledgehammer. damaged severely during the earthquake in Simav; it took half a day for the hydraulic breaker and excavator to reduce it to a mound of mixed rubble.

\section{Discussion on Safety Issues}

Despite the relevant regulations, the demolition industry in Turkey cannot be called regulated. In fact, anyone can call himself a demolition contractor and undertake demolition work of any type and size. Except for one large demolition company in Izmir, company owners were not even primary school graduates. Their lack of education is manifest in their attitude towards worker training and safety.

None of the demolition contractors interviewed in Istanbul, Ankara or Izmir employed the services of a structural engineer to assess the buildings for a safe demolition strategy. They claimed that the bottom-up approach for demolishing floor slabs and the top-down approach for demolishing the skeleton helped to mitigate accidents due to unforeseen structural collapses.

On the other hand, safety precautions are mostly instinctive and fall protection non-existent. The demolition crew does not wear protective helmets or safety belts on the job-site as they consider such gear to be unnecessary and cumbersome. It appears that the workers ignore safety measures because they are over-confident in their expertise and their ability to balance atop precarious perches. Yet, as one contractor covertly confessed, workers do fall off the buildings and deaths have occurred in the past.

The approach to basic worker training reveals the 'learn as you go' attitude of the contractor. There is no formal training to equip workers with knowledge and skills related to the construction trades; whereas, demolition workers need to understand how buildings are constructed so that they can de-construct them safely, rapidly and efficiently. They also need to understand the risks involved, from the point of view of hazardous waste and personal safety, so that they will be motivated to take precautions. As can be seen in Figure 6, the demolition work is proceeding

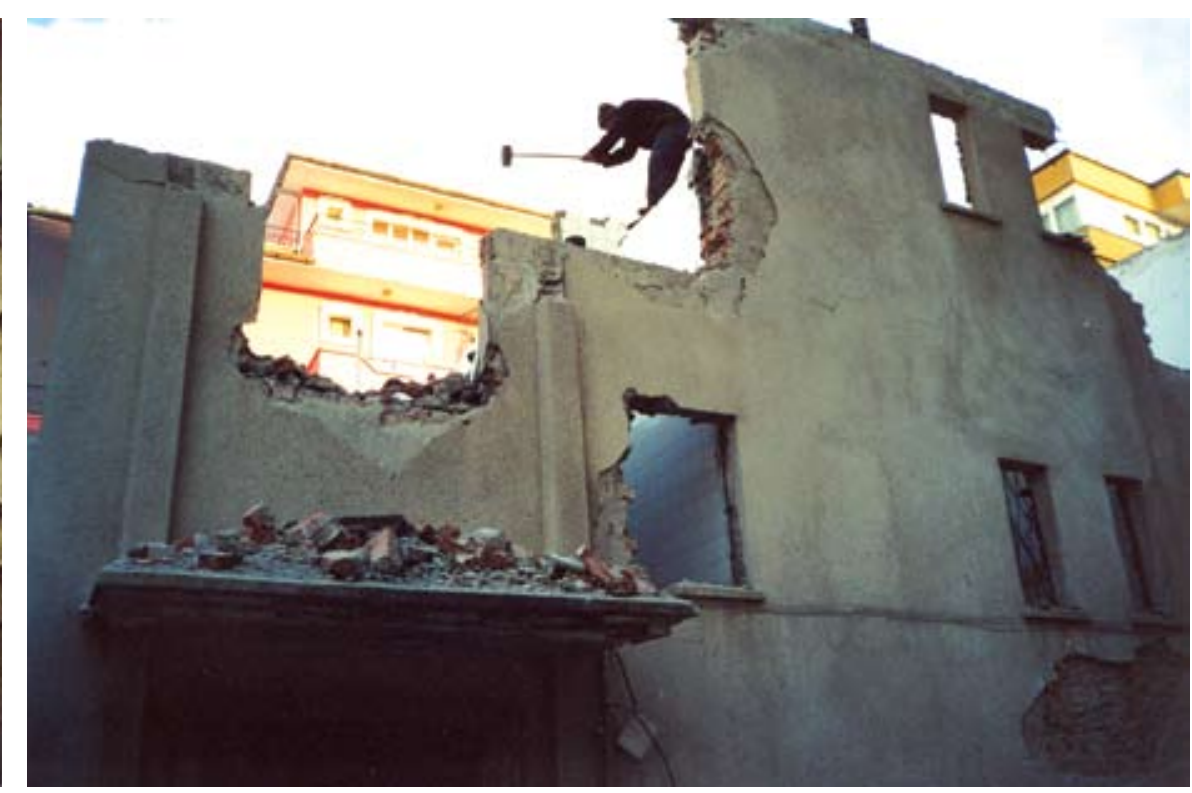

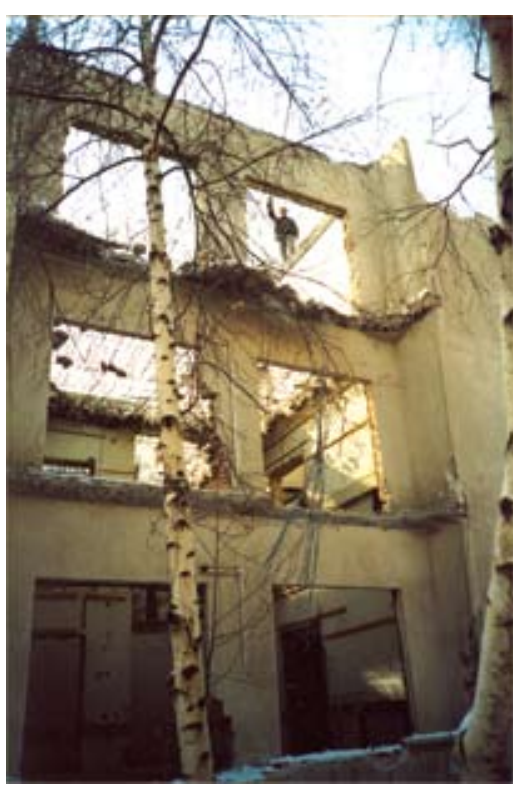


without fall-protection and the worker is demolishing the very wall on which he is standing.

\section{Conclusions and Recommendations}

Usually, buildings or their components are not designed to facilitate deconstruction. The introduction of fast action glues and adhesives has speeded up the assembly and construction process; while concrete mortars and grout also aim to improve durability and weatherproofing. However, these measures are detrimental to the deconstruction process. There was a time when carpenters prided themselves on their demountable joinery and stonemasons were adept at mortar free joints; but such trades and techniques have died out as time is the essence in any enterprise. Products are designed for ease and speed in assembly; and if the design also allows for easy disassembly, it is usually unintentional.

To develop the deconstruction industry in Turkey, improvements have to be made in four main areas; namely, legislation, equipment, worker training and design for deconstruction; in the following manner:

1. The new environmental legislation related to demolition and recycling of building materials is at odds with the existing building codes and standards, which in turn do not allow the use of second hand building material in new construction. This hurdle has to be removed by updating and harmonizing the regulations and building codes.

2. Equipment and tools should be developed to facilitate material salvage without damage.

3. Worker training is crucial not only from the point of view of maximizing material for reuse and recycling, but also from the point of view of the workers' health and safety.

4. The environmental impact of C\&D waste is not common knowledge, neither is the importance of life-cycle assessment of buildings. If these issues are introduced into the curriculum for design education, it will be possible to overcome the existing lack of strategies for design that facilitates deconstruction.

\section{ACKNOWLEDGEMENT}

All photographs were taken by the author except those presented in Figure $\mathbf{5}$ as a collage: Figure 5a, 5d, 5e, $5 \mathrm{f}$ have been downloaded from the Doğan News Agency (DHA) website and Figure $5 b$ and $5 c$ from that of Cihan News Agency (CHA).

\section{REFERENCES}

BLENGNINI, G.A. (2009) Life cycle of buildings, demolition and recycling potential: A case study in Turin, Italy, Building and Environment, 44 (2); 319-30.

CHINI, A.R. (2005) Deconstruction and materials reuse - an international overview, CIB Publication No. 300, University of Florida, Gainesville.

CHA (Cihan Haber Ajans1), Cihan News Agency webpage www.cha.com. $\underline{\text { tr}}$ accessed July 2011.

DHA (Doğan Haber Ajansi), Doğan News Agency webpage www.dha. com.tr accessed July 2011.

ELIAS ÖZKAN, S.T. (2001) Recycling Rubble into Aggregates: A Model for Local Governments. Habitat International, 25 (4); 493-502. 
ELIAS ÖZKAN, S.T. (2002) An overview of demolition, recovery, reuse and recycling practices in Turkey, Design for Deconstruction and Materials Reuse, ed. A.R.Chini and F.Schultmann, CIB Publication 272, Karlsruhe; 128-38.

ELIAS ÖZKAN, S.T. (2003) Deconstruction of earthquake damaged buildings in Turkey, Deconstruction and Materials Reuse - Proceedings of 11th Rinker International Conference on Deconstruction and Materials Reuse, Gainesville, ed. A.R.Chini, CIB Publication No. 287, Rotterdam; 138-50.

ELIAS ÖZKAN, S.T. (2005) The state of deconstruction in Turkey, Deconstruction and Materials Reuse - An International Overview, ed. A.R.Chini, CIB Publication No. 300, University of Florida, Gainesville.

ELIAS ÖZKAN, S.T. and DÜZGÜNEŞ, A. (2002) Recycling of construction material and the reuse of building components: An overview, in the proceedings of the CIB-W107 international conference on Creating a sustainable construction industry in developing countries, CSIR, Pretoria; 265-76.

KIBERT,C.J., CHINI, A. R. and LANGUELL, J. L. (2000) Implementing deconstruction in the United States, in J. Kibert and A. R. Chini (eds) Overview of Deconstruction in Selected Countries, CIB Publication 252, Florida.

Ministry of Development and Housing (2000) Technical Contract for Demolition and Dismantling, Ankara. www.bayindirlik.gov.tr (Yıkma ve Sökme Genel Teknik Şartnamesi, in Turkish).

Ministry of Environment and Forestry (2004) Regulations on Excavation, Construction and Demolition Waste Control, Ankara, www.cevreorman. gov.tr.

Ministry of Environment and Forestry (2008) Waste management action plan: 2008 - 2012 (Atık Yönetimi Eylem Plan 2008-2012 - in Turkish), Ankara. www.cevreorman.gov.tr.

ÖZTÜRK, M. (2005) Regulations for construction and demolition waste management. Ministry of Environment and Forestry, Ankara. (Insaat /Yikinti Atiklari Yonetimi - in Turkish). www.cevreorman.gov.tr

TUIK (2008) Annual Solid Waste Statistics, Turkish Statistics Institute. www. tuik.gov.tr. 
Alınd1: 01.08.2011, Son Metin: 30.12.2011

Anahtar kelimeler: zarar görmüş binalar; atıl binalar; afetler; yıkım; bina sökümü

\section{TÜRKIYE'DE ATIL VEYA DEPREMDE ZARAR GÖREN BINALARIN KISMI SÖKÜMÜ VE YIKIMI}

Binaların kullanım ömürü tükendiğinde veya afetlerde ciddi hasara maruz kaldığında yıkılmak zorunda kalıyor. Türkiyede bina yıkım işlerinin gidişatı ve ilgili mevzuatları; kullanılan makina, ekipman ve teknikleri; hangi malzemenin kurtarıldığı ve hangisinin atıldığını; ve ne şekilde atıldığı hakkında fazla bilgi yoktur. Bu soruların cevaplarını aramak için İstanbul, Ankara ve İzmir'e ilaveten depreme maruz kalan bölgelerde incelemeler yapıldı. İş güveliği konusu araştırmalar sırasında ilgi alanına dahil oldu.

Bu makalede ilgili mevzuatları ve bina yıkım işlerinde takip edilen genel prosedürü hakkında bilgi verilmiştir. Ayrıca atıl veya zarar görmüş binaların kısmi sökümü ve yıkım aşamalarına da yer verilmiştir. Yapılan incelemeler sonucunda bina yıkım işlerinde iş güvenliği ve fizibilitiyi artırıcı tavsiyelerde bulunulmuştur.

SOOFIA TAHIRA ELIAS ÖZKAN; B.Arch., M.S. and Ph.D.

Has her degrees in Building Science. Practised architecture for 17 years, in Pakistan and Turkey, before joining the Department of Architecture at METU. Her research is focused on recovery, reuse and recycling of building material; sustainability, bioclimatic and green architecture, energy-efficiency and building simulations. elias ozkan@yahoo.com 